\title{
IDENTITAS DAN KARAKTERISTIK NABI-NABI ISRAEL DALAM PERJANJIAN LAMA
}

\author{
Sudarman \\ IAIN Raden Intan Lampung \\ sudarlampung@yahoo.com
}

\begin{abstract}
Abstrak
Nabi-Nabi Israel banyak dikemukakan Kitab Suci Agama Kristen, baik Perjanjian Lama maupun Perjanjian Baru. Artikel ini menguraikan konsep kenabian dalam perspektif agama Kristen, terutama dalam Perjanjian Lama. Uraian diawali dengan pemaparan Israel sebagai bangsa, identitas orang pemberani, sosok manusia yang mirip nabi tetapi bukan nabi yang muncul pada bangsa-bangsa sekitar Israel. Tulisan ini juga mengungkap sebutan dan tugas nabi, nabi dan kondisi ekstase, dan nabi dan nubuat. Masing-masing tema yang diuraikan terdiri dari beberapa sub-tema yang dianggap relevan. Nabi-Nabi Israel yang dikisahkan dalam Perjanjian Lama menempati ruang istimewa dalam sejarah kekristenan, bahkan sejarah kenabian Agama Samawi lainnya, seperti Yahudi dan Islam. Keistimewaan para nabi terletak pada status keterpilihannya oleh Tuhan dan panggilan khusus yang diberikan kepada mereka. Seorang nabi memiliki tugas untuk menerima pesan Tuhan melalui wahyu dan menyampaikan pesan tersebut kepada manusia. Nabi adalah orang yang berbicara atas namaTuhan dengan keterlibatan perasaan yang kuat.
\end{abstract}

\section{Abstract}

IDENTITY AND CHARACTERISTICS OF THE PROPHETS OF ISRAEL IN THE OLD TESTAMENT. Prophets of Israel are aplenty expressed in the Christians Scriptures, both the Old Testament and the New Testament. This article outlines the concept of prophethood in the perspective of Christianity, especially in the Old Testament. The story begins with a brief description of Israel as a nation, as the identity of the brave, the human figure which is similar to a prophet but not the prophet who appeared in nations around Israel. This paper also reveals the titles and the duties of the prophet, the prophet and the condition of ecstasy, and prophets and prophecy. Each 
theme described consists of several sub-themes that are considered relevant. Prophets of Israel told in the Old Testament occupies a privileged space in the history of Christianity, even prophetic history of other divine religion like Judaism and Islam. The specialty of the prophets lies on the status of his election by God and a special call given to them. A prophet has the duty to receive the messages of God through revelation and convey the messages to the people. The prophet is someone who speaks for name of the Lord with a strong sense of involvement.

Kata Kunci: Nabi Israel; Perjanjian Lama; Ekstase; Nubuat.

\section{A. Pendahuluan}

Kata nabi dalam tradisi Kristen diyakini berasal dari bahasa Ibrani "navi" yang berarti orang yang mewartakan pesan yang diterimanya dari Roh Ilahi. Seorang nabi, terutama dalam Perjanjian Lama, disebut 'mulut' Yahweh karena mengumumkan pesan kepada manusia apa yang dipesankan oleh Tuhan. ${ }^{1}$ Kata "nabi" sering diartikan dengan "mengangkat", "menunjuk", atau "memanggil". ${ }^{2}$ Kata nabi apabila dipakai dalam bentuk pasif secara etimologis bermakna orang yang dipanggil dan diutus Tuhan dengan suatu tugas tertentu. Secara teologis nabi adalah orang yang berbicara atas nama Tuhan, maka nabi bisa dikatakan legatus Divinus, seseorang yang diutus Tuhan.

Bangsa yang paling banyak disebut di dunia ini, terutama akhir-akhir ini karena aksi beringasnya terhadap Palestina, adalah bangsa Yahudi atau bangsa Israel. Yahudi dikenal sepanjang sejarah dengan lebih satu nama, dimana sesungguhnya antara nama yang satu dengan nama yang lain memiliki konteks yang spesifik. Pada umumnya ada tiga nama yang populer disandang oleh bangsa ini yaitu: bangsa Ibri, bangsa Israel, dan Yahudi itu sendiri.

${ }^{1}$ Theological Dictionary of The New Testamen, Gerhard Kittel dan Gerhard Friedrich (Ed), Trans. Geoffrey W. Bromiley, Vol. VI. (Michigan, Grand Rapids: WM.B.Eerdmans Publishing Company, 1995), h. 781. The New International Dictionary of New Testament Theology. Colin Brown (Ed). Vol.3. (Devon, UK: Exeter The Paternoster Press, 1978), h. 74. Ensiklopedi Gereja, Adolf Heuken (Ed), Jilid VI (Jakarta:Yayasan Cipta Loka Caraka, 2005), h. 9-10. Lihat pula Ensiklopedi Alkitab Masa Kini, Jilid II (Jakarta: Yayasan Komunikasi Bina Kasih, 2005), h. 163.

${ }^{2}$ Leon J. Wood, Nabi-Nabi Isael, judul asli The Prophets of Israel (Malang: Gandum Mas, 2005), h. 83. 
Pertama, sebutan ibri. Kata ibri adalah bentuk kata tunggal, bentukjamaknya adalah ibriyyun. Biasanya disebut juga dengan $i b r a n i$ atau ibraniyyun, yang dinisbatkan kepada Nabi Ibrahim as, karena ia disebutkan dalam Taurat sebagai "Abram orang Ibrani". Kata ibri dalam bahasa Ibrani mempunyai makna pindah, atau melakukan perjalanan, atau menyeberang dari suatu tempat ke tempat lain. Kata tersebut biasanya dihubungkan dengan kenyataan bahwa bangsa ini dalam kenyataan sejarah berpindah-pindah, melakukan suatu perjalanan, atau yang menyeberang ke tempat lain. Beberapa peneliti meyakini bahwa nama ibri diambil dari Eber, nama salah seorang kakek buyut Nabi Ibrahim as.

Beberapa peneliti menghubungkan kata ibri dengan kata abirou atau khabirou yang terdapat dalam banyak referensi Mesir Kuno dan Asyur Babilonia yang terbiasa menggunakan kata-kata ini untuk menyebutkan kabilah-kabilah Arab Badui, diantaranya adalah kabilah Aram, yang disebut sebagai asal muasal Nabi Ibrahim as.

Masih ada makna lain tentang kata ibri, yaitu bahwa kata ini digunakan untuk menunjuk keterasingan suatu bangsa yang menggunakan kata ibri tersebut. Kata ibri banyak digunakan oleh Perjanjian Lama, yang mengandung makna orang asing, juga untuk menyebutkan bahasa suku-suku terasing. Hal tersebut bisa dilacak misalnya pada Perjanjian Lama Kitab Keluaran 21:2; Kitab Ulangan 15:12; dan I Samuel 13:3-4.

Kata ibri juga menunjuk bahasa kelompok-kelompok masa silam, yaitu ibri kuno yang merupakan hasil karya sastera klasik. Sastera ibri adalah sastera yang menggunakan bahasa ibri sebagai sarana ungkapan, disamping sebagai bahasa sehari-hari yang digunakan bangsa Israel dalam beberapa fase sejarah mereka. Pada zaman modern sekarang ini sastera ibri muncul dalam tulisantulisan bangsa Yahudi di Eropa dan Amerika sebagai bahasa tulisan yang merupakan sarana untuk menghidupkan bahasa ibri dan merupakan salah satu tujuan Gerakan Zionis.

Kedua, sebutan Israel. Nama Israel sering menunjuk kepada suatu bangsa yang dilebihkan dari bangsa-bangsa lain. Israel adalah sebuah nama kebanggaan dan keagungan bagi mereka. Nama Israel, menurut Taurat, adalah perubahan nama dari Ya'kub menjadi Israel, yang termuat dalam Perjanjian Lama Kitab Kejadian 
32: 24-32, di mana pada suatu malam Ya'kub bertarung dan berulat dengan tuhan sampai fajar menyingsing, Ya'kub menang dan tuhan kalah, tetapi sendi pangkal paha Ya'kub terluka yang membuatnya pincang. Pada peristiwa itu Tuhan berkata "Namamu tidak akan disebutkan lagi Yakub, tetapi Israel...”. Begitulah asal mula kata Israel, dan itulah sebabnya sekarang ini orang Israel tidak memakan daging yang menutupi pangkal paha.

Kata Israel mempunyai pengertian umum, yaitu penisbatan kepada Israel, Nabi Ya'kub as, seperti telah diuraikan di atas. Penggunaannya diperkirakan dimulai sejak abad ke-19 SM, jika kita menganut prediksi bahwa abad tersebut merupakan masa hidup Nabi Ya'kub as. Disamping pengertian umum, ada pengertian khusus, bahwa Israel adalah mengisyaratkan suatu kecenderungan politik geografi, kerajaan Israel Utara, yang hampir dapat dipastikan dimulai sejak tahun 932 SM, pada saat wafatnya Nabi Sulaiman as, yang kemudian kerajaan Nabi Sulaiman terpecah menjadi dua: kerajaan Yehuda di Selatan dan kerajaan Israel di Utara. Nama Israel ini dipilih oleh Gerakan Zionis modern sebagai identitas yang mengandung makna yang bersifat politis dan geografis.

Ketiga, sebutan Yahudi. Yahudi adalah nama yang diberikan kepada setiap orang yang meyakini Yahudi, mempercayai ajarannya, dan melaksanakan ritualnya. Yahudi adalah penisbatan kepada Agama Yahudi, sebagamana Masehi nisbat kepada al-Masih, muslim nisbat kepada Islam dan seterusnya. Dari sisi ini Yahudi berarti mengandung pengertian murni agama. Pengertian tersebut tidaklah cukup, karena sebutan Yahudi pada kenyataannya mengisyaratkan kecenderungan kepada aliran politik dan geografis tertentu. Dalam pengertian ini tidak bisa dipisahkan Yahudi sebagai agama dan Yahudi sebagai suatu bangsa.

Berikut ini akan diuraikan mengenai konsep kenabian dalam perspektif Agama Kristen, terutama dalam Perjanjian Lama. Uraian diawali dengan pemaparan Israel sebagai bangsa, identitas orang pemberani, sosok manusia yang mirip nabi tetapi bukan nabi yang muncul pada bangsa-bangsa sekitar Israel, sebutan dan tugas, nabi dan kondisi ekstase, dan diakhiri oleh uraian mengenai nabi dan nubuat. Masing-masing tema yang diuraikan terdiri dari beberapa sub-tema yang dianggap relevan. 


\section{B. Israel Sebagai Bangsa}

Muhammad Khalifah Hasan $^{3}$ membagi sejarah dan perkembangan bangsa Israel menjadi enam fase sebagai berikut. Pertama, periode agama para leluhur. Leluhur yang dimaksudkan adalah tokoh-tokoh yang mendahului Nabi Musa as dalam tradisi kuno. Para leluhur yang paling terkenal adalah Ibrahim, Ishak, Yakub, dan anak-anak Yakub yang merupakan asal usul suku-suku bangsa Israel. Ada sebagian peneliti yang memasukkan Adam dan Nuh ke dalam kelompok para leluhur bangsa Israel, tetapi tetap saja yang menjadi fokus leluhur Israel bermuara pada Ibrahim. Silsilah para leluhur ini berakhir pada diri Musa as. Fase pertama ini perkembangan Agama Yahudi ditandai dengan agama sederhana yang tidak rumir, dan karakter nomaden, seperti Bangsa Arab sebelum Islam.

Kedua, periode Nabi Musa as. Agama yang dibawa oleh Nabi Musa as merupakan fase kedua dari perkembangan Agama Yahudi, yaitu fase yang benar-benar dianggap sebagai fase terpenting dalam perkembangan agama ini. Pada periode ini berlangsunglah pengenalan bangsa Israel terhadap Tuhan yang mereka sebut Yahweh, dalam bentuk yang jelas dan diperkenalkan akan nama dan karakteristik Yahweh untuk pertama kalinya. Jika sbelumnya kepercayaan orang Israel adalah politheisme-paganisme di bawah asuhan Nabi Musa as agama orang-orang Israel benar-benar berubah menjadi monotheisme. Doktrin ang sangat penting apa periode ini diantaranya adalah doktrin perjanjian. Sebenarnya doktrin ini telah ada pada masa 'para leluhur' hanya saja tidak menjadi doktrin Agama Yahudi, kecuali pada periode Nabi Musa as. Pada periode Musa juga ditandai dengan diturunkannya aturan dan hokum-hukum syari'at, dalam bentuk perintah dan larangan, yang dijadikan oleh Nabi Musa as untuk mengadili bangsa Israel.

Ketiga, periode sesudah Musa hingga Kerajaan Israel terpecah. Setelah orang-orang Israel eksodus dari Mesir, mereka harus tinggal dan menetap cukup lama di Kan'an, selama tiga abad, sejak mereka masuk Kan'an abad 13 SM sampai berdirinya kerajaan Daud dan Sulaiman pada abad 10 SM. Lingkungan orang Kan'an yang

${ }^{3}$ Muhammad Khalifah Hasan, Sejarah Agama Yahudi, Penerjemah Abdul Somad dan Faisal Saleh (Jakarta: Pustaka Al-Kautsar, 2009), h. 185-209. 
agraris dan menetap, memaksa orang-orang Israel yang nomaden menyesuaikan diri, termasuk bentuk kepercayaannya. Di sinilah pembentukan negara untuk pertama kalinya dalam sejarah bangsa Israel. Nomaden menjadi agraris dan menetap, yang mengambil bentuk kesatuan kabilah dan berakhir dengan mengambil bentuk negara.

Kerajaan Daud dan Sulaiman dimaknai oleh orang-orang Israel sebagai sebuah peristiwa penting, yaitu terwujudnya perjanjian tertulis dari Tuhan sebelumnya, yaitu janji berupa tanah. Janji berupa tanah dan jumlah yang banyak yang pernah dianugerahkan kepada para leluhur dan terulang kembali pada masa Musa, sekarang menjadi kenyataan. Daud dan Sulaiman berhasil memindahkan Tabut (Tabut Perjanjian) ke Yerusalem dan mendirikan Haikal di sana, menumbuhkan perasaan religious di sekitar kota baru tersebut, dan muncullah kepercayaan bahwa Bukit Zion adalah tempat Yahweh yang abadi.

Suasana religious dan taat kepada Tuhan kembali pudar dengan meninggalnya Nabi Sulaiman as. Orang-orang Israel mulai berpikir bahwa kerajaan Daud dan Sulaiman adalah kerajaan biasa, bukan kerajaan yang dijanjikan Tuhan. Adalah Yerobeam (922-901 SM) yang mempelopori propaganda tersebut, bahkan dia berhasil memindahkan ibukota dan pusat peribadatan orang-orang Israel ke bagian Utara dengan pesatnya di Betel dan Dan, sementara sebagian mereka masih tetap bertahan di bagian selatan, dengan pusatnya di Yerusalem. Sejak saat itu orang-orang Yahudi terpecah menjadi dua kelompok kerajaan, Selatan dan Utara. Pada bagian Utara, ketika dipimpin oleh Ahab, masuklah keyakinan-keyakinan paganism yang menyembah berhala, terutama Ba'al. Pada masa iniah muncul nabi-nabi yang memerangi paganism dan penyembahan berhala seperti Elia, Yesaya, dan orang-orang sesudah mereka, khususnya Amos dan Hosea.

Keempat, periode tawanan dan kenabian klasik. Peristiwaperistiwa politik terus berlanjut setelah perpecahan menjadi dua yaitu bagian Selatan dan bagian Utara. Puncak dari krisis ini adalah runtuhnya kerajaan Utara di tangan Asyur pada 721 SM dan runtuhnya kerajaan Selatan di tangan bangsa Babel tahun 586 SM. Bangsa Israel praktis menjadi bangsa tawanan penguasa Asyur 
dan Babel. Dalam situasi seperti itu muncullah beberapa nabi, yang disebut para nabi klasik, yaitu nabi-nabi yang menyerukan perlunya kembali kepada ajaran Nabi Musa as. Para nabi ini ternyata disamping engajarkan untuk kembali kepada ajaran Musa yang ideal, tetapi juga menyerukan tugas-tugas sosial dan perbaikan moral. Lewat ajaran baru para nabi ini muncul persepsi baru mengenai perjanjian, khususnya menurut Yeremia, yang berbicara tentang Perjanjian Baru yang berbeda dengan Perjanjian Lama. Kandungan Perjanjian Baru adalah pengakuan akan dosa manusia, dimana ketaatan sebuah bangsa kepada Tuhan menjadi tidak terjamin diakibatkan oleh pengabaian perjanjian oleh mansia, kecuali ada anugerah Tuhan kepada manusia. Demkianlah kira-kira sampai masa Ezra dari Babel ke Yerusalem pada akhir abad ke-5 SM. Selesailah penetapatan hukum syari'at menurut Taurat yang ditulis oleh Ezra.

Kelima, masa Yunani dan periode Talmud. Ketika Agama Yahudi mengakhiri masa tawanan dan masa Persia, sebagai agama dapat dikatakan telah mencapai kesempurnaan. Selama dua periode tersebut, dengan pengaruh para nabi di satu sisi dan pengaruh Persi dan Babel di sisi lain, kesempurnaan agama tersebut tercapai dengan kembali kepada ajaran Musa as. Masa stabil tersebut semakin membaik dengan adanya situasi politik yang semakin baik, dimana orang Yahudi diizinkan kembali ke Palestina, berakhirnya penawanan oleh bangsa Babel, dibangunnya kembali Haikal, dan kembalinya Yerusalem sebagai pusat kehidupan orang Yahudi.

Bersamaan dengan berakhirnya masa Persia, ditandai penaklukan AlexanderThe Great (Aleksander Agung) ke Timur Dekat, dimulailah babak baru yang sama sekali berbeda dibandingkan periode sebelumnya. Jika sebelumnya pada masa Mesir, Asyur, Babel dan Persia agama Yahudi cukup kuat bertahan, saat ini berhadapan dengan serangan pemikiran Yunani, yang membawa metodologi pemikiran, di mana akal dibenturkan dengan wahyu, yang seolaholah ada kesan peradaban Yunani lebih mengunggulkan akal daripada wahyu. Metodologi Yunani adalah metodologi logika.

Sebagai reaksi terhadap gempuran pemikiran rasional Yunani maka orang-orang Yahudi terbagi menjadi tiga kelompok, 
yaitu kelompok yang menerima pemikiran Yunani, kelompok yang menolak secara keras, dan kelompok yang berusaha memadukan antara ajaran Agama Yahudi dengan pemikiran rasional Yunani. Pada situasi seperti inilah muncul pada akhir abad ke-5 Masehi satu babak dalam Agama Yahudi yang disebut periode Talmud. Talmud dianggap penting karena ia merupakan catatan dan pedoman hukum-hukum agama yang mengatur kehidupan orang Yahudi.

Keenam, periode Kristen dan Islam. Hubungan antara Yahudi dan Kristen adalah hubungan yang menegangkan sejak awal. Ketegangan tersebut berawal dari masalah-masalah teologis, diantaranya yang sangat serius bahwa kaum Yahudi menolak bahwa Isa AS adalah messias dan juruselamat, dan secara tegas orang-orang Yahudi menolak ketuhanan Isa AS. Berbeda dengan hubungan Yahudi Kristen yang selalu diwarnai perseteruan sengit, perjumpaan antara Agama Yahudi dan Islam sejak awal adalah perjumpaan yang baik dan damai. Nabi Muhammad ketika tampil membawa ajaran Islam, membiarkan orang-orang Yahudi hidup dengan keyakinannya, keculai orang-orang yan secara sadar memilih memeluk Islam. Harus diakui, pernah terjadi beberapa konflik antara orang-orang Yahudi dankaum muslimin, baik di Mekkah maupun Madinah, tetapi harus dicatat bahwa konflik tersebut tidak diakibatkan oleh masalah teologis, tetapi lebih karena masalah ekonomi dan politik.

\section{Identitas Orang-orang Pemberani}

Nabi-nabi Israel menempati ruang istimewa dalam sejarah kenabian Kristen bahkan sejarah kenabian agama samawi lainya, Yahudi dan Islam. Tidak ada negeri lain selain Israel yang mempunyai jumlah nabi yang sebanding dengan mereka. ${ }^{4}$ Di Israel peran para nabi bagi kehidupan keagamaan penduduknya tidak dapat diremehkan, kendatipun masih terdapat cukup banyak

${ }^{4}$ Lihat Theodore H. Robinson, Prophecy and The Prophets in Ancient Israel (London: Gerald Duckworth \& Co, 1960), terutama pada bab satu dan bab dua. Robert R. Wilson membandingkan nabi-nabi di Israel dengan tempat-tempat lain seperti Mesopotamia, Mesir, Palestina dan Siria, dengan kesimpulan bahwa jumlah nabi di Israel lebih banyak dibandingkan dengan negeri lain, lihat Robert R. Wilson, Prophecy and Society in Ancient Israel (Philadelphia: Fortress Press, 1980), h. 89-134. 
penyelewengan dari Hukum Tuhan, ${ }^{5}$ namun tanpa para nabi tersebut kemungkinan penyelewengan akan jauh lebih parah.

Nabi-nabi Israel yang paling termasyhur adalah para nabi penulis, yaitu para nabi yang kitab-kitabnya merupakan bagian penting dari Perjanjian Lama, namun sesungguhnya nabi-nabi Israel bukanlah hanya mereka. Nabi-nabi paling awal adalah yang menulis kitab nubuat secara khusus pada abad sembilan Sebelum Masehi. Jauh sebelum nabi-nabi tersebut telah ada Nabi Musa, Samuel, Natan, Elia, Elisa, dan banyak lagi lainnya. ${ }^{6}$ Para nabi tersebut sering terlupakan ketika orang membahas kenabian dalam Kristen karena memberikan penekanan kepada para nabi yang datang kemudian, tetapi sesungguhnya para nabi tersebut sama pentingnya dengan nabi-nabi yang menulis kitab-kitab nubuat. Umumnya, nabi-nabi Israel terbagi menjadi tiga golongan, ${ }^{7}$ pertama nabi-nabi masa pra-kerajaan, dimana perhatian utama diarahkan untuk mencegah umat agar tidak mengikuti praktik-praktik bangsa Kanaan. Golongan kedua, adalah nabi-nabi zaman kerajaan yang menulis buku dimana penekanan usaha mereka adalah mengontak individu-individu. Golongan ketiga adalah para nabi penulis yang misinya lebih ditujukan pada seluruh bangsa dan dosa umat manusia pada umumnya.

Para nabi Israel, sama seperti nabi-nabi lain, adalah orangorang yang mendapat panggilan khusus. Mereka tidak memperoleh kedudukan karena warisan, karena dilahirkan dalam keluarga para nabi, anak seorang nabi tidak secara otomatis menjadi nabi, tetapi setiap nabi dipilih secara khusus oleh Tuhan dan dipanggil untuk melakukan suatu pekerjaan yang ditetapkan Tuhan baginya. Jabatan kenabian berbeda dengan jabatan imam di Israel, karena imam mendapatkan kedudukan berdasarkan warisan. Jika seseorang

${ }^{5}$ R.E. Clements, Prophecy and Tradition (Oxford: Basil Blackwell, 1975), h. 4157. Lihat juga Claus Westemann, Basic Form of Prophetic Speech (London: Lutterworth Press, 1967), h. 204.

${ }^{6}$ Theodore H. Robinson, Prophecy...h. 28-38.

${ }^{7}$ Pembagian kenabian menjadi tiga seperti ini lazim dipergunakan oleh para ahli agama Kristen, hanya saja para ahli tersebut tidak selalu menggunakan istilah "kerajaan", Costen J. Harrel, misalnya, membagi periodisasi itu menjadi periode Assiria, periode Chaldea dan periode Persia dan Yunani. Lihat Costen J. Harrel, The Prophets of Israel (Nashville, Tenn, USA: Cokesbury Press, 1933). 
merupakan keturunan Lewi anak Yakub, maka dia seorang Lewi, sementara jika seseorang lahir menjadi anak Harun, maka dia adalah seorang imam. Dia tidak perlu memilih untuk menjadi seoran Lewi atau seorang imam, dia juga tidak perlu mendapat panggilan untuk mendapat salah satu jabatan itu, dia mendapatkan salah satu atau kedua-duanya karena kelahiran. Berbeda dengan imam, para nabi adalah orang-orang yang diplih diantara banyak orang. Hal inilah yang membuat para nabi menduduki tempat terhormat, karena dipanggil secara khusus oleh Tuhan. ${ }^{8}$

Panggilan Tuhan kepada seseorang untuk menjadi nabi sering diberikan bersamaan dengan suatu peristiwa luar biasa untuk membantu menyadarkan nabi itu akan keotentikannya. Musa dipanggil ketika menyaksikan semak-semak secara ajaib, Yesaya mendapat penglihatan akan Tuhan yang tinggi menjulang di dalam Bait Allah ketika dia menerima pangilannya, Yehezkiel disuruh memakan gulungan Alkitab pada waktu dia dipanggil. ${ }^{9}$

Panggilan untuk menjadi nabi sering kali juga meliputi beberapa aspek persiapan bagi pekerjaan yang akan datang. Musa dibekali dengana beberapa tanda untuk menunjukkan kekuasaannya, dan didampingi oleh Harun abangnya sendiri sebagai juru bicaranya. Bibir Yesaya disucikan dengan bara api yang diambil langsung dari atas mezbah dan disentuhkan pada bibirnya. Yehezkiel, setelah memakan gulungan Kitab, secara simbolik telah dipenuhi oleh Firman Tuhan sehinga dapat mewartakannya secara efektif. ${ }^{10}$

Seorang nabi sering menerima tugas berat, ia harus merintis jalan yang sama sekali baru dibandingkan sebelumnya, meskipun Tuhan memberinya petunjuk tentang pekerjaan yang harus dilakukan dan jalan yang harus ditempuh, sering kali ia masih menerima banyak tantangan di jalan itu. Tugasnya dapat membawanya kepada bahaya besar atau kehormatan luar biasa. Tindakan pertama Samuel sebagai nabi yang baru dipanggil Tuhan adalah memberitahukan kepada Eli, sang imam besar,

${ }^{8}$ Leon J. Wood, Nabi-Nabi Israel, terj. Tim Gandum Mas (Malang: Gandum Mas, 2005), h. 13-15.

${ }^{9} \mathrm{Tbid}$.

${ }^{10}$ Ibid. 
bahwa keluarganya telah ditolak Tuhan. Tentu ini tugas berat bagi Samuel. Kelak Samuel harus mengurapi Raja pertama Israel, Saul, dan setelah itu dia juga harus memberitahukan kepadanya bahwa keluarganya telah ditolak Tuhan. ${ }^{11}$ Kemudian ia harus juga mengurapi raja Israel yang kedua, Raja Daud yang agung. Suatu saat Nabi Natan diperintah Tuhan untuk menegur Daud karena dosanya dengan Betsyeba, sebuah tantangan berat menghadapi raja terbesar ketika itu, tetapi Natan melakukannya. Tiga tahun kemudian Nabi Gad harus menegur dan memberikan tiga pilihan hukuman kepada Raja Daud karena dosanya melakukan sensus. Nabi Ahia pertamatama harus menjanjikan kerajaan Israel yang baru kepada Yerobeam dan kemudian harus mengatakan kepadanya tatkala kerakjaan akan diambil darinya. Seorang "abdi Alah" diutus untuk menegur Yerobeam karena mezbah palsu yang didirikannya di Betel. Elia memberi peringatan akan adanya kekeringan dan kelaparan dan menyelenggarakan suatu kontes spektakuler di Gunung Karmel. Elisa memberitahukan kepada Hazael bahwa dia akan menjadi raja atas Siria, dan menangis ketika mengatakannya karena dia tahu bahwa orang ini akan mendatangkan malapetaka kepada Israel. Yunus diutus ke kota Niniwe yang asing dan menakutkan untuk menyerukan pertobatan.

Semua ini menunjukkan bahwa orang-orang yang menjadi nabi haruslah orang-orang yang benar-benar istimewa, mempunyai watak yang menonjol, otak yang cemerlang dan jiwa yang berani. Mereka mempunyai sifat-sifat tersebut secara alami, dan setelah menyerahkan diri kepada Tuhan, mereka akan menjadi jauh lebih hebat karena tugas dan perlengkapan khusus yang dipercayakan kepada mereka. Para nabi menjadi tokoh raksasa bagi bangsa Israel, pembentuk pandangan umum, pemimpin pada masa kegelapan, orang yang dibedakan dari orang lain di sekitar mereka, baik diantara bangsa Israel maupun bangsa-bangsa lain pada zaman itu.

\section{D. "Nabi-Nabi" di Sekitar Bangsa Israel}

Israel bukanlah sebuah negeri yang berdiri sendiri pada zamannya, yang bebas dari pengaruh bangsa-bangsa lain, melainkan

${ }^{11}$ J. Lindblom, Prophecy in Ancient Israel (Oxford: Basil Blackwell, 1962), h.83. 
merupakan suatu bangsa diantara bangsa-bangsa lain yang saling mempengaruhi. Ada perbedaan pendapat mengenai sejauh mana Israel telah terpengaruh oleh bangsa lain, terutama dalam hal keberagamaan. Ada yang mengatakan pengaruh tersebut sangat besar, tetapi ad pula yang mengatakan tidak terlalu besar. Terlepas dari besar atau tidaknya, pengaruh tersebut diakui oleh Alkitab, misalnya ada orang Israel yang menyembah Baal, dewa orang Kanaan. ${ }^{12}$

Mengingat paham kenabian sangat sentral di kalangan Israel, dan karena ada sejenis paham kenabian juga di dunia di luar Israel pada masa itu, maka penting kiranya untuk mempertimbangkan pertanyaan apakah Israel meminjam praktik nubuat tersebut dari bangsa-bangsa di sekitarnya. Ada berbagai pandangan yang berbeda mengenai pertanyaan ini. Gustav Holscher, misalnya, merasa yakin bahwa hampir semua aspek nubuat Israel ditiru dari bangsa Kanaan. ${ }^{13}$ Sebaliknya J. Lindblom tidak percaya bahwa Israel meniru bangsa Kanaan, tetapi yang lebih tepat adalah melakukan praktik nubuat karena seluruh dunia juga melakukannya. ${ }^{14}$ Orang Israel juga sama dengan bangsa lain dan melakukan kegiatan keagamaannya seperti bangsa lain. Abraham Heschel, dengan mengamati ayat-ayat Alkitab secara lebih mendalam, melihat nabi-nabi Israel sebagai orang yang unik dan tulisan mereka menempati kelas tersendiri. ${ }^{15}$

Dalam kaitan ini setidaknya relevan dibahas tiga negara yang mempunyai singgungan erat dengan Israel yaitu Mesopotamia, Mesir dan Kanaan. Pertama, Mesopotamia yang menduduki tempat unik di kawasan Timur Tengah pada masa Perjanjian Lama. Negara yang berhubungan langsung dengan Israel sesungguhnya bukan Mesopotamia melainkan Kanaan, tetapi bangsa Kanaan sangat dipengaruhi oleh Mesopotamia, ketika terjadi perpindahan besarbesaran bangsa Mesopotamia ke Kanaan pada awal millennium kedua sebelum Masehi. ${ }^{16}$

${ }^{12}$ Hak. 2:13, 14; 3:7,8; 6:25-30.

${ }^{13}$ Gustaf Hölscher Die Propheten (Leipzig: Hinrichts, 1914), hlm. 140 sebagaimana dikutip Leon J. Wood, Nabi-Nabi Israel...,.h. 28.

${ }^{14} \mathrm{~J}$. Lindblom, Prophecy in Ancient Israel.., h. 98.

${ }^{15}$ Abraham J. Heschel, The Prophets (New York: Harper \& Row, 1962), h. 472473.

${ }^{16}$ Robert R. Wilson, Prophecy and Society...h. 90. 
Agama menduduki tempat yang istimewa bagi orang Mesopotamia. Jarang orang melakukan sesuatu atau memutuskan sesuatu di luar kepentingan agama dan kehendak dewa-dewa. Mereka mempunyai imamat untuk melayani kuil-kuilnya. Ada empat kelas imam dalam menjalankan praktik keagamaan: yang pertama adalah Ashipu, bertugas mengusir roh jahat, dipercaya dapat membebaskan orang dari pengaruh iblis; yang kedua Kallu, yang bertanggungjawab atas penyelenggaraan musik di kuil; yang ketiga Qadishtu, imam wanita, yang rupanya fungsi utamanya adalah semacam pelacuran agamawi; dan keempat suatu kelompok yang terdiri dari empat imam Baru, Sha'ilu, Shabru dan Mahhu, yang mempunyai fungsi bersama dalam hal pertenungan dan merupakan yang terpenting dari semuanya. Diantara keempatnya imam Baru dianggap yang paling penting. Orang-orang datang kepada para imam untuk mengajukan pertanyaan dan mereka menanggapi dengan apa yang mereka anggap sebagai jawaban ilahi dengan memakai berbagai teknik. Sarana praktik pertenungan dibagi menjadi dua kelompok, yang tidak diatur dan yang diatur. Kelompok yang diatur menyangkut segala macam kejadian seharihari yang dianggap sebagai pertanda. Kelompok pertanda yang tidak diatur menyangkut gejala alam, benda-benda langit, cara terbang burung, mimpi dan keadaan cuaca.

Kedua, bangsa Mesir. Wilayah penting lain yang memberikan pengaruh kuat kepada Kanaan adalah Mesir, sama seperti di Mesopotamia agama memegang peranan penting di Mesir, walaupun dalam beberapa hal berbeda dengan Mesopotamia. Sejak masa-masa awal kerajaan Mesir, imam mempunyai pengaruh kuat di negeri itu. Pada masa dinasti yang ke delapan belas, abad enam belas sampai empat belas SM, para imam telah menjadi sangat kaya, dan pada masa Raja Ramses III para imam menguasai sekitar sepersepuluh bagian negeri itu. ${ }^{17}$

Ada tiga tingkatan imam yang diakui. Uab, bertugas memeriksa hewan untuk kurban dan menjalankan tugas-tugas rutin di sekitar kuil. Kherheb, seorang terpelajar yang dapat menyebutkan semua liturgi dengan benar dan memberi petunjuk tentang tata cara upacara. Hemu neter, merupakan imam paling penting, kurang lebih

${ }^{17}$ Ibid., h. 124 . 
sama dengan imam Baru di Mesopotamia, bertanggunjawab dalam kegiatan yang berhubungan dengan upacara ilahi. Ada banyak bentuk pertenungan di Mesir, tetapi yang paling penting adalah mengenai mimpi. Selain mimpi yang populer adalah pengamatan terhadap fenomena alam terutama bintang-bintang dan mengenai gerakan hewan-hewan yang dikeramatkan. ${ }^{18}$

Pada tahun 2000 SM diperoleh beberapa karangan tentang keadilan sosial yang konon telah menjadikan pengarangnya "nabinabi" masyarakat. Ipu-wer merupakan penulis yang paling penting, tulisannya dikenal berciri nubuat dari Mesir yang paling mirip dengan kitb nubuat Israel. Ia tanpa mengenal rasa takut mengecam kebobrokan raja yang memerintah dan kerusakan sosial yang ditimbulkannya. Dia menunjukkan perbedaan diantara raja itu memerintah dan bagaimana seharusnya seorang raja yang ideal memerintah. "Nabi" sosial yang lain adalah Nefer-rohu, hidup ketika raja Snefru memerintah. Ciri utama nubuat ini adalah pada apa yang disebut sifat mesianik, yaitu bahwa Nefer-rohu menunjuk seorang raja yang akan datang menyelamatkan Mesir. ${ }^{19}$

Ketiga, bangsa Kanaan. Kebudayaan Kanaan banyak mempengaruhi Israel. Di Kanaan banyak terdapat kuil yang di dalamnya dipersembahkan hewan kurban dan juga wanita-wanita suci memberi pelayanan sebagai pelacur bakti. Dewa kepala bernama El, tetapi dewa yang dianggap orang Kanaan paling penting adalah Baal. Dalam arti tunggal Baal dianggap sebagai dewa seluruh bangsa, dalam arti jamak sebagai manifestasi lokal dari dewa nasional. ${ }^{20}$

\section{E. Sebutan dan Tugas}

Ada tiga istilah khusus yang penting dalam menyebut nabi. Pertama adalah nabhi' yang umumnya diterjemahkan menjadi "prophet" dalam bahasa Inggris atai "nabi" dalam bahasa Indonesia. Kata ini dipakai hampir tiga ratus kali dalam Perjanjian Lama hanya dalam bentuk kata bendanya saja. ${ }^{21}$ Dua istilah lainnya

\footnotetext{
${ }^{18}$ Leon J. Wood, Nabi-Nabi Israel...h. 24.

${ }^{19} \mathrm{Ibid}$.

${ }^{20}$ Lihat Bil. 25:3; Bil. 32:38; Hak. 3:3.

${ }^{21}$ David L. Petersen, The Roles of Israel's Prophets (England: University of
} Sheffield, 1981), h. 58. 
jauh lebih jarang dipakai. Keduanya diterjemahkan menjadi "seer" dalam bahasa Inggris atau "pelihat" dalam bahasa Indonesia. Dua istilah yang bermakna seer itu yang pertama adalah ro'eh, dari kata "melihat" dan yang lain adalah hozeh, dari akar kata hazah, artinya "melihat". Ada satu lagi istilah keempat yang perlu dikemukakan meskipun yang keempat ini paling sedikit digunakan, yaitu "abdi Allah" ('ish elohim), artinya cukup jelas ia menunjuk kepada nabi sebagai orang yang telah dipilih dan diutus oleh Tuhan. ${ }^{22}$

Tugas dari orang-orang yang disebut dengan istilah-istilah ini pada dasarnya dijabarkan menjadi dua bagian di dalam Perjanjian Lama. Pertama adalah menerima pesan dari Tuhan melalui wahyu dan yang kedua menyampaikan pesan itu kepada manusia. Tidak semua nabi digambarkan menerima tugas yang pertama tetapi semuanya menerima tugas yang kedua. Sangat mungkin beberapa diantaranya, kalau tidak dapat dikatakan banyak, menyampaikan pesan yang mereka pelajari dari nabi-nabi lain atau mereka buat berdasarkan kebutuhan pada zaman itu sebagaimana diilhamkan oleh Tuhan, namun beberapa nabi menerima ilham secara langsung dari Tuhan melalui pewahyuan secara adikodrati. ${ }^{23}$ Dalam tradisi Israel, selain nabi, imam juga mempunyai tugas rangkap, meskipun dalam bentuk yang sedikit berbeda. Kewajiban para imam adalah mempersembahkan kurban atas nama umatnya, dan yang kedua adalah menyampaikan pesan Tuhan kepada manusia. Perbedaan tugas para nabi dengan para imam terletak pada cara mereka menyampaikan pesan, para imam mengajarkan umat dengan bahan Hukum atau Taurat yang Tuhan berikan di Bukit Sinai, sementara para nabi mendesak dan menasehati orang untuk mentaati Hukum. Para imam lebih memusatkan perhatian pada otak manusia, memberitahukan kepada manusia apa yang harus mereka ketahui, sedangkan nabi memusatkan perhatian pada perasaan dan kehendak mereka, mendesak orang agar melakukan apa yang telah mereka ketahui. ${ }^{24}$

Persamaan lainnya antara nabi dan imam adalah dalam hal pewahyuan. Imam, terutama imam-imam besar, juga mempunyai

${ }^{22}$ Ibid., h. 35.

${ }^{23}$ Ibid., h. 71.

${ }^{24}$ Leon J. Wood, Nabi-Nabi Israel...h. 20. 
suatu cara menerima pesan dari Tuhan. Mereka diberi alat yang disebut Urim dan Tumim. Tidak banyak diketahui bagaimana cara kerja Urim dan Tumim ini, yang jelas ia ada hubungannya dengan efod yang dikenakan oleh imam besar sebagai kelengkapan pakaiannya, dan dengan cara ini mereka dapat memprakarsai dan menerima wahyu Tuhan. Para nabi, sebaliknya, tidak mempunyai cara untuk memprakarsai datangnya wahyu ilahi. Para nabi hanya menunggu sampai Tuhan sendiri menetapkan saat yang tepat untuk memberikan informasi. Pada waktu informasi datang, bentuk dan isinya jauh lebih berbobot daripada yang diterima oleh imam besar melalui Urim dan Tumimnya. ${ }^{25}$

\section{F. Nabi dan Keadaan Ekstase}

Banyak ahli berpendapat bahwa dalam bernubuat nabinabi Israel kehilangan kesadaran dan hanyut dalam perasaan yang meluap-luap, terutama nabi-nabi yang pertama. Bahkan ada yang merasa yakin bahwa pada zaman itu kemampuan untuk keluar dari alam sadar dan hanyut dalam perasaan yang meluap-luap adalah cirri penting untuk mengakui keaslian seorang nabi. Konon, orang Israel meniru fenomena ini dari Kanaan. Banyak yang berpendapat bahwa fenomena ini merupakan salah satu pengaruh utama Kanaan pada perkembangan kenabian di Israel. Jauh sebelum itu, Kanaan mendapat pengaruh dari Asia kecil. Theophile J. Meek berpendapat bahwa gerakan itu menyebar dari Asia Kecil menjelang millennium kedua SM sampai ke Yunani di satu sisi dan Ayur serta Palestina di sisi yang lain. ${ }^{26}$ Theodore H. Robinson menambahkan bahwa pada masa selanjutnya fenomena ini meluas sampai ke seluruh Timur Tengah. Lama-kelamaan fenomena ini meluas menyebar ke seluruh dunia. E.O.James memberikan daftar dari wilayah-wilayah yang paling menonjol dan mengatakan bahwa mungkin Delfi merupakan pusat kegiatan ekstase kuno. ${ }^{27}$

Beberapa jenis ekstatisme hanya dilakukan sebagai suatu ritual dalam beberapa peserta perayaan pesta tertentu, tetapi jenis, yang dibandingkan dengan nubuat, didorong oleh keinginan untuk

\footnotetext{
${ }^{25}$ Ibid., h. 20-21.

${ }^{26}$ Theophile J. Meek, Hebrew Origins (New York: Harper, 1960), h. 55.

${ }^{27}$ Theodore H. Robinson, Prophecy...h. 39-49.
} 
mengetahui kehendak ilahi (wahyu). Dalam usaha memasuki dunia roh, orang perlu melepaskan ikatan dengan alam nyata. Untuk mencapai kondisi ekstatik dipakai berbagai cara termasuk uap beracun, tarian suci, musik dengan irama tertentu, atau bahkan narkotik. Akal sehat harus ditinggalkan dan pikiran dikosongkan untuk menerima pesan-pesan dari dunia roh.

Model nubuat seperti tersebut yang diyakini dianut juga oleh para nabi Israel, terutama pada masa awal biasanya dikaitkan dengan zaman Samuel. Masyarakat sering bertanya tentang segala sesuatu kepada mereka tentang kehendak ilahi, dan mereka akan mencari jawabannya dalam keadaan ekstase. Karena penampilan mereka seperti orang kesurupan dan tariannya yang aneh, mereka sering disebut meshugga', “orang gila”. Dalam Alkitab memang ada perikop-perikop yang memungkinkan orang berargumrntasi mengenai ekstatisme kenabian Israel ini. ${ }^{28}$

Penganut pandangan ekstase mendasarkan argumentasi pada perikop-perikop Alkitab tersebut, yang pandangan mereka dapat dikelompokkan menjadi tujuh kategori sebagai berikut: pertama, perbandingan dengan agama-agama lain. Maksudnya perbandingan agama Israel dengan apa yang lazim terjadi di dunia saat itu. Orang Israel tinggal bersama orang-orang Kanaan yang mempunyai kebiasaan ekstase gila-gilaan karena masuk dalam sistem agama orang Kanaan. Kedua, pengaruh bukit pengorbanan Kanaan. Rombongan nabi yang dijumpai Saul dalam perjalanan pulang setelah diurapi oleh Samuel sedang "turun dari bukit pengorbanan”. Kegiatan untuk melakukan kegiatan keagamaan di atas bukit (bamah) adalah khas Kanaan, jadi masuk akal untuk menyimpulkan bahwa nabi-nabi Israel terpengaruh oleh praktik agama bangsa Kanaan.

Ketiga, alat musik. Telah diketahui bahwa musik telah dipakai negeri-negeri lain sebagai suatu cara untuk membangkitkan ekstatik. II Raja-Raja 3 mencatat peristwa Elisa berkata kepada

${ }^{28}$ Perikop yang dipakai sebagai bukti dari pandangan ekstatisme para nabi terdiri dari dua yaitu perikop utama dan perikop pendukung. Perikop utama terdiri dari tiga yaitu a) Bil. 11:25-29 b) I Sam. 10:1-13 c) I Sam. 19: 18-24. Perikop pendukung: a) menunjukkan arti meracau I Sam. 18: 10; I Raj. 18: 29; I Raj. 22: 10-12. b) menunjukkan arti gila II Raj. 9: 1-12; Yer. 29:26 dan Hos. 9:7. 
ketiga raja, Yosafat dari Yehuda, Yoram dari Israel, dan Raja Edom, bagaimana mereka mendapatkan air yang sangat mereka butuhkan pada saat itu. Elisa minta dipanggilkan pemain kecapi untuk memainkan musik sehingga Elisa dapat mencapai keadaan ekstatik, dan dalam keadaan demikian ia dapat berkomunikasi dengan Tuhan. Keempat, Saul berubah menjadi manusia lain. Kelima, Saul terbaring tidak sadarkan diri selama berjam-jam. Dalam I Sam. 19 menceritakan Saul bertemu dengan nabi-nabi Samuel ketika Daud dilarikan ke Rama, Saul tidak hanya kepenuhan seperti nabi tetapi juga menanggalkan paling tidak sebagian pakaiannya dan berbaring tidak sadarkan diri sepanjang siang dan sepanjang malam. Keenam, nubuat dari ketujuh puluh tua-tua. Peristiwa kepenuhannya tujuh puluh orang tua-tua Israel di padang gurun sebagaimana dikisahkan dalam Bil.11. Ketujuh, keterlibatan Roh Allah. Istilah Roh Allah dimaksudkan sebagai kuasa, yang dianggap ilahi, yang menyebabkan ekstatik kegila-gilaan.

\section{G. Nabi dan Nubuat}

Ada dua istilah yang akan dijelaskan di bagian ini yaitu ro'eh dan hozeh, istilah yang tidak sering dipakai untuk menyebut nabi, dan istilah kedua yaitu Abdi Allah (Manusia Allah).

Pertama, istilah ro'eh dan hozeh. Kata ro'eh dipakai sebanyak dua belas kali dalam Perjanjian Lama dan kata hozeh delapan belas kali. Ini jauh lebih sedikit dibandingkan dengan istilah utama nabhi', namun kedua istilah tersebut tetap mengandung sesuatu yang penting untuk dipelajari. Kata ro'eh dan hozeh berasal dari kata kerja yang mempunyai arti sama. Kata ro'eh berasal dari kata kerja ra'ah dan kata hozeh berasal dari kata hazah, keduanya berarti "melihat". Secara umum Perjanjian Lama menerjemahkannya dengan "pelihat". ${ }^{29}$

Morris Jastrow memberikan gagasan perbedaan ro'eh dan hozeh bahwa ro'eh adalah pelihat bagi masyarakat umum sedangkan hozeh terutama bekerja sebagai peramal resmi kerajaan. ${ }^{30}$ Pendapat yang lebih masuk akal menyangkut waktu dimana kedua istilah

\footnotetext{
${ }^{29}$ David L. Petersen, The Roles...h. 38.

${ }^{30}$ Morris Jastrow, "Ro'eh and Hozeh in The Old Testament”, Journal of Biblical Literature, Nomor 52 Tahun 1909, h. 28.
} 
itu lazim dipakai. Keduanya mempunyai masa populeritasnya masing-masing: ro'eh pada masa Samuel, dimana delapan dari dua belas kemunculannya terdapat pada masa ini, dan hozeh pada masa Daud, karena empat dari tujuh orang yang disebut dengan istilah itu hidup pada zaman ini. Ayat pada I Sam. 9:9 secara khusus menyebutkan bahwa istilah pelihat (ro'eh) telah berubah dalam popularitas pemakaiannya menjadi nabhi'. Dalam nas ini memang tidak disebut-sebut tentang istilah hozeh, tetapi apabila ro'eh dapat berubah menjadi nabhi', pasti hozeh juga demikian. ${ }^{31}$

Perjanjian Lama membedakan antara ro'eh-hozeh dengan imam besar dalam pemakaian Urim dan Tumim. Urim dan Tumim adalah alat yang diberikan Tuhan kepada imam besar untuk menyatakan kehendak Tuhan mengenai masalah-masalah tertentu. Ketika sedang memakai alat ini imam besar juga dapat disebut sebagai "pelihat" karena dia juga dapat mengetahui kehendak Tuhan. Tetapi setidaknya terdapat tiga hal yang membedakan kegiatan imam besar dengan ro'eh-hozeh. Pertama bahwa Urim dan Tumim dapat dipandang sebagai alat lahiriah untuk membantu mengajukan pertanyaan, hal ini ditunjukkan oleh kenyataan bahwa ia ditaruh pada "tutup dada" efod yang dipakai imam besar. Orang yang disebut ro'eh-hozeh tidak pernah digambarkan memakai alat semacam itu. Kedua, dengan memakai alat ini, imam besar dapat memulai satu turunan petunjuk dari Tuhan, meskipun adakalanya Tuhan tidak memberi jawaban, sebaliknya ro'eh-hozeh tidak pernah digambarkan memulai suatu pewahyuan. Ketiga, pertanyaan yang diajukan imam besar selalu menyangkut urusan resmi di Israel, tetapi hampir semua topik pertanyaan yang dianggap penting dapat diajukan oleh ro'eh-hozeh, misalnya mengenai hewan peliharaan Saul yang hilang. ${ }^{32}$

Kedua, istilah Abdi Allah (Manusia Allah). Sebutan yang ketiga adalah "abdi Allah" ('ish elohim), dipakai misalnya untuk menyebut orang yang mengecam mezbah palsu di Betel, dan kemudian ditahan oleh nabi tua di Betel. Arti yang ditunjukkan di sini hanyalah bahwa orang itu mengenal Tuhan dan diutus Tuhan dalam suatu misi khusus. Istilah ini juga dipakai untuk menyebutkan

\footnotetext{
${ }^{31}$ Leon J. Wood, Nabi-Nabi Israel...h. 80-81.

${ }^{32}$ Ibid., h. 81-82.
} 
nabi-nabi yang namanya telah dikenal. ${ }^{33}$ Sebutan utama bagi nabi adalah nabhi', dalam bentuk kata benda saja dipakai hampir tiga ratus kali, dan kata ini erat kaitannya dengan kata kerjanya nabha', yang juga digunakan kurang lebih tiga ratus kali. Genesius mengemukakan bahwa kata nabha' berarti “meluap-luap” sesuai dengan perilaku ekstase nabi-nabi dalam keadaan perasaan penuh gairah dan meluap-luap. Theophile Meek mengatakan bahwa kata kerja ini harus diakitkan dengan kata Akkadian nabu yang bentuk aktifnya berarti "berbicara" dan dengan demikian memberikan gagasan "pembicara". ${ }^{4}$ William F. Albright mendukung pendapat ini tetapi ia mengatakan karena nabu pada umumnya digunakan dalam bentuk pasif maka bentuk istilah yang harus diambil untuk etimologi nabhi'. Ini memberikan arti "orang yang diajak bicara" atau "orang yang dipanggil" sehingga lebih menekankan panggilan kepada orang itu untuk melayani. ${ }^{35}$ Pendapat ini didukung oleh H.H. Rowley yang melihat adanya hubungan dengan kata Arab naba'a yang berarti "mengumumkan" yang pada waktu itu diangap sebagai "pembicara” atau bahkan dengan akar kata Ibrani bo' yang berarti "datang" atau "masuk" ${ }^{36}$

Nabi adalah orang yang berbicara bagi Tuhan dengan keterlibatan perasaan yang kuat. Tugas mereka bukan hanya menyampaikan berita; mereka harus menyampaikan pesan-pesan vital yang akan mengubah hidup. Mereka harus berbicara penuh semangat. Jadi tepatlah untuk menyimpulkan bahwa makna seutuhnya dari "bernubuat" adalah "berbicara bagi Tuhan dengan penuh semangat”.

Pertanyaan yang telah membangkitkan banyak perdebatan tentang siapa yang menulis kitab para nabi, yaitu apakah para nabi yang namanya dipakai sebagai judul kitab menulis sendiri kitabnya atau orang yang mengetahui ajarannya yang menuliskannya.

Lindblom ${ }^{37}$ berpendapat bahwa orang lain yang menulisnya,

${ }^{33}$ David L. Petersen, The Roles...h. 40-49.

${ }^{34}$ Theophile J. Meek, Hebrew Origins...h. 147.

${ }^{35}$ William F. Albright, From The Stone Age to Christianity $2^{\text {nd }}$ ed. (New York: Doubleday Anchor Books, 1957), h. 231.

${ }^{36}$ H.H. Rowley, Prophecy and Religion in Ancient China and Israel (New York: Harper, 1956), h. 4.

${ }^{37}$ J. Lindblom, Prophecy and Ancient Israel... h. 59 dst 
bahwa semua nabi besar mempunyai banyak pengikut yang belajar dari mereka dan mau membantu dengan senang hati baik untuk melayani secara lisan atau mencatat informasi dari mereka. Dia menduga bahwa meungkin kelompok itu merupakan keturunan dari kelompok serupa pada zaman nabi-nabi awal yang disebut rombongan nabi. Dia berpendapat bahwa tugas orang ini adalah mendengarkan baik-baik ketika nabi berbicara, menanamkan pesanpesan itu dalam benak mereka, bahkan sampai menghafalkannya dengan cara mengulang-ulang dengan tekun, dan melestarikannya demi kepentingan generasi yang akan datang. Di antara alasan yang dikemukakan Lindblom adalah bahwa dalam teks tertulis ada begitu banyak perikop yang tidak jelas, begitu banak ketidaksesuaian isi, begitu banyak nas-nas kembar dan terdapat begitu banyak tambahan dalam kitab para nabi. ${ }^{38}$

Berbeda dengan Lindblom, Leon J. Wood berpendapat bahwa memang benar Tuhan dapat pula mengilhamkan informasi melalui satu atau lebih pengikut nabi, tetapi nabi sendirilah yang diilhami untuk mengkhotbahkannya sepanjang hidup, dialah yang paling mengetahui informasi itu, oleh karena itu dialah yang paling mungkin terilhami untuk melestarikannya dalam bentuk tulisan. Wood berpandangan jika nabi memakai sekretaris, seperti Yeremia memakai Barukh, itu tetap berarti bahwa nabi itu sendirilah pengarangnya, Barukh hanya menuliskan apa yang didektekan oleh Yeremia. $^{39}$

\section{H. Penutup}

Para nabi Israel, sama seperti nabi-nabi lain, adalah orangorang yang mendapat panggilan khusus. Mereka tidak memperoleh kedudukan karena warisan, karena dilahirkan dalam keluarga para nabi, anak seorang nabi tidak secara otomatis menjadi nabi, tetapi setiap nabi dipilih secara khusus oleh Tuhan dan dipanggil untuk melakukan suatu pekerjaan yang ditetapkan Tuhan baginya. Jabatan kenabian berbeda dengan jabatan imam di Israel, karena imam mendapatkan kedudukan berdasarkan warisan.[]

\footnotetext{
${ }^{38}$ Ibid., h. 164.

${ }^{39}$ Leon J. Wood, Nabi-Nabi Israel...h. 177.
} 


\section{Daftar Pustaka}

Brown (Ed), Colin, The New International Dictionary of New Testament Theology.. Vol.3. Devon, UK: Exeter The Paternoster Press, 1978.

Clements, R.E., Prophecy and Tradition, Oxford: Basil Blackwell, 1975.

Ensiklopedi Alkitab Masa Kini, Jilid II, Jakarta: Yayasan Komunikasi Bina Kasih, 2005.

Harrel, Costen J., The Prophets of Israel, Nashville, Tenn, USA: Cokesbury Press, 1933.

Heuken (Ed), Adolf, Ensiklopedi Gereja, Jilid VI , Jakarta: Yayasan Cipta Loka Caraka, 2005.

Hasan, Muhammad Khalifah, Sejarah Agama Yahudi, Penerjemah Abdul Somad dan Faisal Saleh , Jakarta: Pustaka Al-Kautsar, 2009.

Heschel, Abraham J., The Prophets, New York: Harper \& Row, 1962.

Hölscher, Gustaf Die Propheten , Leipzig: Hinrichts, 1914.

Kittel, Gerhard dan Friedrich (Ed), Gerhard, Theological Dictionary of The New Testamen, Trans. Geoffrey W. Bromiley, Vol. VI. Michigan, Grand Rapids: WM.B.Eerdmans Publishing Company, 1995.

Robinson, Theodore H., Prophecy and The Prophets in Ancient Israel, London: Gerald Duckworth \& Co, 1960.

Meek, Theophile J., Hebrew Origins, New York: Harper, 1960.

Petersen, David L., The Roles of Israel's Prophets, England: University of Sheffield, 1981.

Westemann, Claus, Basic Form of Prophetic Speech , London: Lutterworth Press, 1967.

Wilson, Robert R., Prophecy and Society in Ancient Israel, Philadelphia: Fortress Press, 1980.

Wood, Leon J., Nabi-Nabi Israel, terj. Tim Gandum Mas, Malang: Gandum Mas, 2005.

, Nabi-Nabi Isael, judul asli The Prophets of Israel, Malang: Gandum Mas, 2005. 